\title{
Strategies for the Management of Traditional Chestnut Landscapes in Pesio Valley, Italy: A Participatory Approach
}

\author{
Paola Gullino ${ }^{1}$ (D), Maria Gabriella Mellano ${ }^{1,2}$, Gabriele Loris Beccaro ${ }^{1,2}$, Marco Devecchi ${ }^{1,3}$ (D) \\ and Federica Larcher $1,3, *$ (D) \\ 1 Department of Agricultural, Forest and Food Sciences, University of Turin, Largo Paolo Braccini 2, \\ 10095 Grugliasco TO, Italy; paola.gullino@unito.it (P.G.); gabriella.mellano@unito.it (M.G.M.); \\ gabriele.beccaro@unito.it (G.L.B.); marco.devecchi@unito.it (M.D.) \\ 2 Chestnut R\&D Center-Piemonte, Largo Paolo Braccini 2, 10095 Grugliasco TO, Italy \\ 3 Research Centre for Rural Development of Hilly Areas, University of Torino, Largo Paolo Braccini 2, \\ 10095 Grugliasco TO, Italy \\ * Correspondence: federica.larcher@unito.it
}

Received: 19 October 2020; Accepted: 18 December 2020; Published: 21 December 2020

\begin{abstract}
Through an exploratory case study conducted in the Pesio Valley, northwest Italy, this paper proposes a framework for maintaining traditional chestnut production landscapes and addressing future development policies. The main goal was to understand how to promote a bottom-up planning approach, including stakeholder perceptions in traditional chestnut landscape management. To ensure the sustainability of the landscape, current driving forces and their landscape effects were identified by local stakeholders using a focus group technique. Population ageing, local forestry policies directed towards supporting chestnut growers' income, social and economic needs, and land fragmentation are the main driving forces that will influence future chestnut landscapes. The focus group participants built two scenarios of possible future development of the chestnut landscape, one characterized by the disappearance and transformation of chestnut stands, the other by their permanence and maintenance. The most recommended strategies for maintaining traditional chestnut cultivation were chestnut processing, fruit designation of origin, and the cultivation of traditional varieties. This study shows that, to preserve the traditional chestnut landscape, the participation of multiple stakeholders is a useful approach in landscape planning. This methodology could guide decision-makers and planners who desire to implement a participatory approach to a sustainable development program for traditional chestnut landscapes.
\end{abstract}

Keywords: Castanea sativa; local participation; cultural heritage; scenarios; land use; conservation

\section{Introduction}

In Europe, all agroforestry systems are landscapes managed by traditional agricultural techniques or practices [1,2]. Currently, traditional landscapes are receiving much attention from researchers and planners with multiple aims, including biodiversity preservation and conservation of cultural values [3]. The concept of traditional landscapes is linked to their cultural and historical features, to the maintenance over the centuries of the same land uses and cultivation techniques. As reported by Antrop [4], remnants of traditional landscapes still exist in Europe nowadays, but they have become isolated patches on a large scale and are more and more difficult to recognize. In this context, several authors have outlined that many traditional land use systems have been lost or diminished in the past decades $[5,6]$. This process is mainly linked to the abandonment or degradation of traditional agricultural systems and forestry management. Moreover, these sites have been subject to 
transformations following land abandonment or crop conversion caused by processes towards more intensification and urbanization [7].

Castanea sativa Miller woodlands are an important part of the forestry ecosystem in Italy and are considered a primary food source for middle mountain landscape populations [8]. Moreover, in the Piedmont region (northwest Italy), chestnuts have historically represented one of the most important land use types [9]. Nutritional traits of chestnuts have always been considered valuable and have been particularly appreciated by the local population. In the mountain area of the Piedmont region, since the Middle Ages, many products have been obtained from the chestnut for food use, from the fruit and the flour that is ground from it. Not only the fruit was used, but also the leaves, for the bedding of livestock in stables or for mattresses, and as components of fertilizer. The softer suckers, which grow at the base of the plant, were considered good forage for goats. The tannin from the bark was used for leather tanning. For this reason, the mountain population of Piedmont has been defined as a "chestnut society", because historically it lived on chestnut products. Fire events in wooded areas, transformations in land uses, and land abandonment in marginal areas are the main cause of increasing unmanaged woodland, linked with the decrease of traditional practices and the loss of biodiversity [10-12]. The current changes of traditional forestry systems are considered a threat linked also to the loss of regional identity and cultural heritage values $[13,14]$. For this reason, conservation of traditional land use including forestry systems is an international priority. In 2004, the Food and Agriculture Organization (FAO) addressed the relationship between agricultural heritage systems and their landscape and outlined the need to safeguard traditional agroforestry systems as cultural landscapes over time (Globally Important Agricultural Heritage System Project) [15]. Furthermore, the traditional rural landscape has been recognized as both a cultural heritage and a common good by international organizations such as the United Nations Educational Scientific and Cultural Organization (UNESCO) under the World Heritage Convention [16].

\section{Research Aim}

The Mediterranean area is characterized by landscape patterns whose composition results from long and complex cultural and historical processes. In particular, the Italian landscape is composed of a rich mosaic of rural and forest landscapes that have been shaped through time $[17,18]$. The sweet chestnut (C. sativa Miller) is the only native species of the genus Castanea in Europe. Moreover, the European chestnut forests are concentrated in just a few countries with a long tradition of chestnut cultivation: France and Italy together account for $79.3 \%$ of the whole chestnut forest area; Spain, Portugal, and Switzerland $(9.7 \%)$ are further contributors, and the remaining areas $(11.0 \%)$ are located in other countries [8]. In Italy, chestnut forests cover an area of 800,000 hectares: 70\% of these are managed as aged coppices with around 30-80 trees/ha, the remaining 30\% being orchards for fruit production [19]. C. sativa is, in general, a tall and vigorous tree; it can exceed $30 \mathrm{~m}$ in height and 400 years in age, in exceptional conditions [20].

In the Piedmont region in northwest Italy, the chestnut landscape is a traditional forestry system with historical and cultural value [9]. Piedmont hosts a rich heritage of genetically diverse varieties including many endangered cultivars. Chestnut cultivation has a wide distribution and also involves some very popular cultivars such as "Marrone" [21]. Today the cultivated area has decreased, leading to social, economic, and ecological consequences [22]. Since 1950, several factors have caused the gradual abandonment of chestnut cultivation: the loss of population from mountain areas, the change in people's diet and culture, and the many pests and diseases that have affected chestnut trees [23]. Moreover, traditional chestnut management approaches (i.e., coppices, high forests, orchards) require continuous labor-intensive inputs. In the absence of management, chestnut stands tend to be invaded by other species and to evolve towards mixed deciduous forests [24]. From this perspective, according to different studies, new integrated approaches to agroforestry system management are needed and the involvement of local stakeholders is considered a priority [25-28]. With the aim to develop integrated plans and policies for the future, a preliminary methodological and multidisciplinary study was 
performed, outlining the need to understand thoroughly the perception that stakeholders have of land use changes [23]. Therefore, the present paper mainly focuses on the participatory study and proposes a methodological framework for addressing future policies for chestnut landscape conservation.

\section{Material and Methods}

\subsection{Study Area}

The study was carried out in the Pesio Valley, Cuneo province, Italy. The current characteristics of chestnut groves and their location in the territory are the result of the process of regression of chestnut cultivation on a regional scale (Figure 1). In Piedmont, a large area of traditional chestnut is still preserved in the valleys of Cuneo province, and some characteristic elements of this traditional landscape are well-preserved in the Pesio Valley [9]. This area includes many mountain valleys and the Chiusa Pesio municipality ( $44^{\circ} 19^{\prime} 25^{\prime \prime}$ North, $7^{\circ} 40^{\prime} 37^{\prime \prime}$ East; $485-2651 \mathrm{~m}$ a.s.1.). In Chiusa Pesio, as reported by the Italian Statistical National Institute (ISTAT, 2014), there are 280 farms that grow chestnut trees for a total of 300 ha of cultivated surface [29].

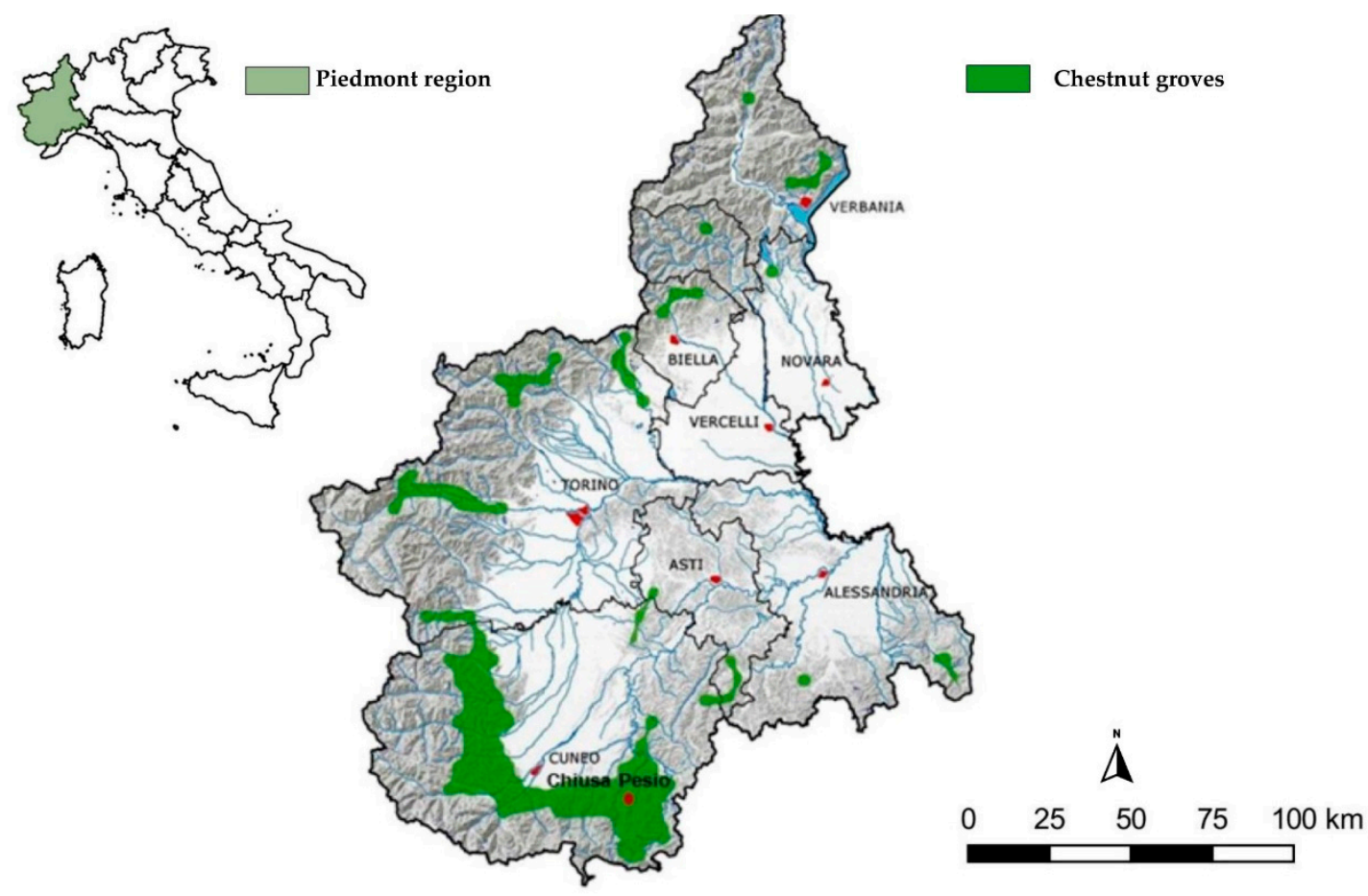

Figure 1. Localization of chestnut groves in Piedmont region (Italy).

The main historical elements that characterize the Pesio Valley landscape are: (i) the cultivation of the Marrone di Chiusa Pesio, a traditional chestnut cultivar used for the production of marrons glacés; (ii) the presence of many other cultivars with different uses (fresh, dried, and candied); (iii) the presence of the Certosa di Pesio, a center of religious and civil life, which has played a fundamental role in the promotion of agriculture and of chestnut cultivation over time; and (iv) the presence of historical rural structures used for chestnut drying [30]. The land use history of the Pesio Valley was strongly influenced by the arrival of the Carthusian monks in 1173. The monks managed woodlands according to the different altitudinal zones: chestnut was cultivated at low altitudes, mainly for the nuts; beech for firewood at mid altitudes; and silver fir for round timber at higher altitudes. This model of silvicultural management was used by the Carthusians at all their monasteries throughout the Alps and Apennines. In other valleys in the Piedmont region, the chestnut cultivation was limited to only one function [31]. In some areas, local varieties are grown, suitable for drying and flour production. These sites are characterized also by the presence of many architectural structures used for chestnut 
drying; some areas have cultivars suitable for processing or fresh consumption (boiled or roasted). In Pesio Valley, chestnuts were intended for different functions. Indeed, in this valley, the cultivation of chestnut was mainly linked with the many and versatile uses of the processed products. Many varieties were traditionally cultivated for certain fruit quality traits that were appreciated by consumers: the sweet chestnut was used in confectionery (candied, syrup, marrons glacés), for production of flour or dried chestnuts, or for fresh consumption (boiled or roasted). The timber is today still sought after in carpentry for the construction of furniture, flooring, paneling or casing, and tannin extraction.

\subsection{Methodological Framework}

In order to define the main driving forces related to traditional chestnut system changes and their landscape effects, and to evaluate future scenarios, a focus group was used as a local participatory technique [32]. As explained by Gullino et al. (2018), the focus group is a qualitative research technique that involves a small number of stakeholders. The focus group should include the main community representatives and should cover a variety of interests, aspirations, expectations, and points of view [33]. In this exploratory research, different actors with different opinions and different roles were involved as stakeholders. Table 1 lists the participants of the focus group. These were: (i) people who have an economic interest (chestnut growers, agricultural institutions, and chestnut food and wood industrial producers); (ii) people who have governance and planning interests (local administrators, local and regional organizations); (iii) people who have nature and agroforestry interests (protected area managers); and (iv) people who have a research interest (academic researchers). All stakeholders involved had a connection with the traditional chestnut landscape and the ability to influence landscape changes directly or indirectly. In particular, chestnut growers, advised by agricultural consultants, are the main users whose activities contribute directly to land use change. Representatives of public bodies and protected area organizations with their policies and forestry programs contribute directly to governance and planning in the chestnut landscape. In contrast, stakeholders that process chestnut or wood have an indirect connection with the chestnut landscape, such as professionals forest agronomists and researchers. Indeed, these stakeholders are affected by the decisions of chestnut growers and/or politicians. The politicians were included in the category "public body representative".

Table 1. Number of stakeholders involved in the focus group.

\begin{tabular}{cc}
\hline Stakeholder Category & Number of Participants (Number Invited) \\
\hline Public body representative & $4(5)$ \\
Protected area organization representative & $2(3)$ \\
Agricultural consultant & $1(1)$ \\
Chestnut grower & $4(4)$ \\
Freelance professional & $3(3)$ \\
Academic researchers & $3(3)$ \\
Chestnut nuts industrial producer & $3(3)$ \\
Chestnut wood industrial producer & $2(2)$ \\
\hline Total & $22(24)$ \\
\hline
\end{tabular}

The panel focus group was organized as a one-day meeting with two main goals. The first goal was to identify the main driving forces related to chestnut system changes and their landscape effects (Session 1); the second was to analyze possible future chestnut scenarios (Session 2). Session 1 focused on the importance of the driving forces perceived by each participant. After the presentation of the research aim, all the focus group participants discussed the concept of the traditional chestnut system and the future of chestnut cultivation. Subsequently, they highlighted which current driving forces might alter the chestnut landscape during the next 20 years. Then, each focus group participant was asked to imagine the two primary possible effects of such driving forces, writing them on individual cards. Each participant explained his/her decisions to the others. The focus group organizers collected the cards and immediately composed a poster that displayed the focus group's perceived driving 
forces with their potential effects (positive or negative). Finally, participants assigned a shared score related to the importance of the current driving forces over the next 20 years (from $1=$ low importance to $5=$ high importance) in relation to the identified effects. In this step, focus group participants as a group decided on a score to assign to each driving force. The assignment of the values was the result of an open discussion among participants and permitted classification of the importance of driving forces.

Session 2 focused on the evaluation of chestnut landscape scenarios. With the aim of identifying future scenarios of the chestnut landscape, in accordance with Loupa Ramos (2010) and Ramirez et al. (2015), several pictures were shown to the focus group participants $[34,35]$. Subsequently, traditional elements linked to chestnut trees' cultivation were listed and explained to participants. Finally, the participants were asked to think creatively, combining or adding elements to create their own "more probable" scenarios in the next 20 years. In particular, each focus group participant created her/his scenario selecting those elements considered more realistic and achievable. With the aim of analyzing stakeholders' opinions, the disappearance/transformation scenario (Figure 2) and the permanence/maintenance scenario (Figure 3) related to the chestnut landscape were constructed and evaluated.

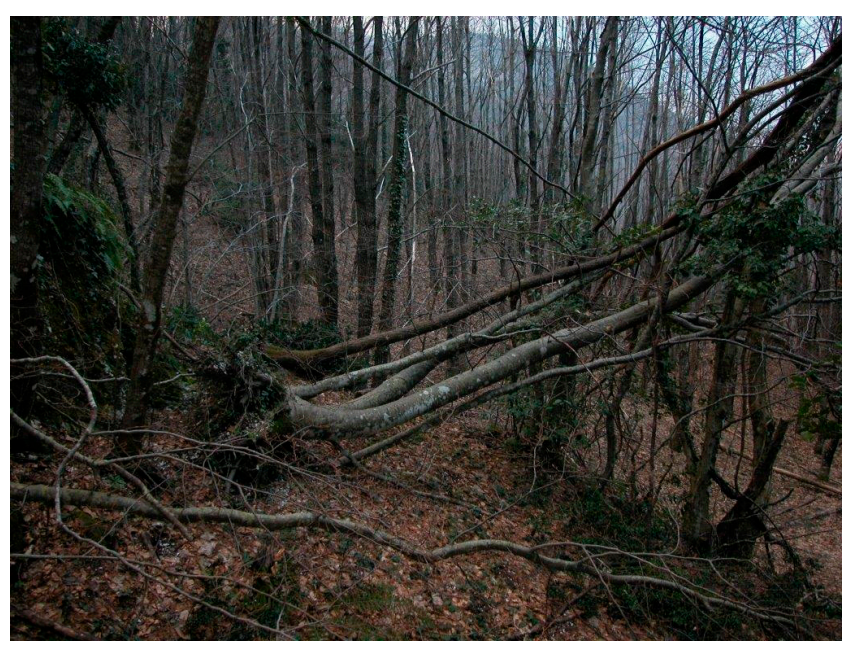

Figure 2. Representation of disappearance/transformation scenario.

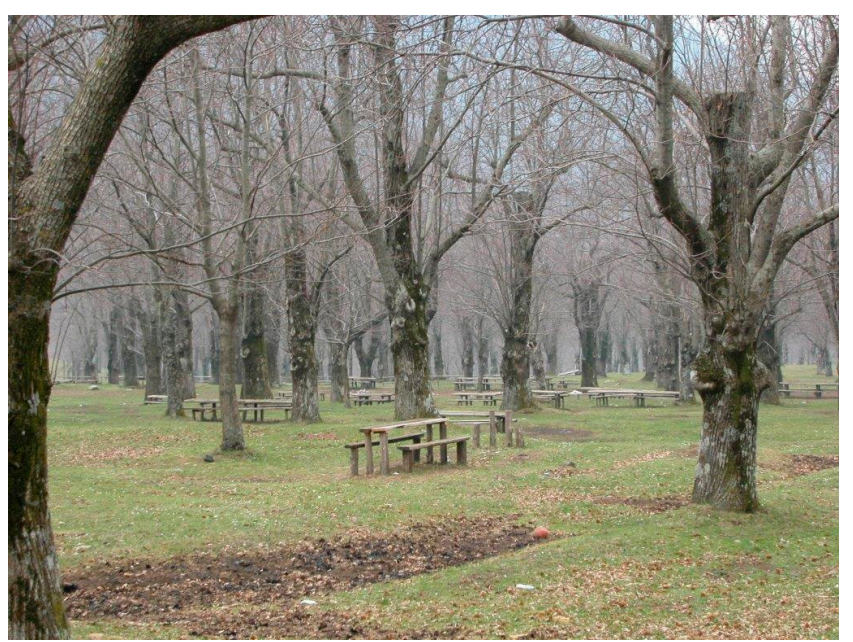

Figure 3. Representation of permanence/maintenance scenario. 


\section{Results}

\subsection{Traditional Chestnut Landscape: Driving Forces and Landscape Effects}

The analysis of the focus group results allowed the identification of the driving forces affecting the chestnut landscape. In session 1, participants identified many driving forces that could have negative $(-)$, positive $(+)$ or variable $(/)$ effects on the traditional chestnut landscape. Table 2 lists the driving forces identified by the focus group participants in terms of their landscape effects and importance (score). Population ageing, local forestry policies supporting chestnut growers' income, social and economic needs, and land fragmentation are the most important driving forces of the chestnut landscape (score 5/5). Demand from young chestnut growers aged 25-40 years (score 3/5) and the economic crisis of intensive fruit growing (score 2/5) are considered secondary.

Table 2. Importance of driving forces identified by the participants of focus group and effects on the traditional chestnut landscape.

\begin{tabular}{|c|c|c|}
\hline $\begin{array}{l}\text { Importance Score } \\
\qquad(1-5)\end{array}$ & Driving Forces & $\begin{array}{c}\text { Influence on Landscape over Next } 20 \text { Years }\left({ }^{\prime}+{ }^{\prime}=\right. \\
\text { Unanimously Positive Effect; ' }-{ }^{\prime}=\text { Unanimously } \\
\text { Negative Effect; ' } / \text { ' = Variable Opinions Regarding } \\
\text { the Effect) }\end{array}$ \\
\hline 5 & Population ageing & $\begin{array}{l}\text { (-) Abandonment of chestnut tree cultivation } \\
\text { (-) Changes of land use } \\
\text { (-) Forest planning problems } \\
\text { (-) Increased abandoned wood areas }\end{array}$ \\
\hline 5 & Land fragmentation & $\begin{array}{l}\text { (-) Abandonment of chestnut tree cultivation } \\
(-) \text { Abandonment of ancient orchards } \\
\text { (-) Management problems } \\
\text { (-) Forest planning problems } \\
\text { (-) Lack of an origin denomination or a specific } \\
\text { protection system } \\
\text { (-) Loss of traditions and local knowledge (loss of } \\
\text { cultural landscape) }\end{array}$ \\
\hline 5 & $\begin{array}{l}\text { Local forestry policies directed } \\
\text { towards supporting } \\
\text { chestnut growers' income }\end{array}$ & $\begin{array}{l}\text { (+) Conservation of traditional and historical } \\
\text { varieties } \\
\text { (+) Preservation of cultural and historical values } \\
\text { (+) Valorization of traditional landscape features } \\
\text { (+) Strengthening of chestnut tree systems } \\
\text { (+) Development of forest planning } \\
\text { (+) Consolidation of cultivation practices and } \\
\text { traditional agroforestry methods connected to quality } \\
\text { fruit production } \\
\text { (-) Spread of new Japanese hybrids more productive } \\
\text { on flat land }\end{array}$ \\
\hline 5 & Social and economic needs & $\begin{array}{l}\text { (/) Demand for bigger fruits and stronger varieties } \\
(+) \text { Valorization of traditional varieties }\end{array}$ \\
\hline 3 & $\begin{array}{l}\text { Demand from } \\
\text { young chestnut growers }\end{array}$ & $\begin{array}{l}\text { (+) Preservation of ancient orchards } \\
(+) \text { Maintaining forest resources and traditional } \\
\text { chestnut trees }\end{array}$ \\
\hline 2 & Economic crisis of intensive chestnut growing & $\begin{array}{l}\text { (+) Relocation of chestnut orchards on flat land } \\
\text { (+) Increase chestnut cultivation } \\
\text { (-) Spread of Japanese hybrids } \\
\text { (-) Decrease of local varieties' } \\
\text { (-) Loss and deterioration of local and traditional } \\
\text { production }\end{array}$ \\
\hline
\end{tabular}

Regarding the landscape effects of driving forces, the focus group participants outlined several differences: the abandonment of chestnut cultivation; abandonment of chestnut tree cultivation, changes of land use, forest planning problems and the increased abandoned wood areas are the main negative effects related to the ageing population. The focus group participants outlined that the abandonment of chestnut tree cultivation has led to the increase of invasive species, causing serious ecological problems and threatening local biodiversity. Furthermore, the abandonment of ancient orchards, sometimes still productive; management and forest planning problems; the loss of traditions 
and local knowledge; and the lack of an origin denomination related to the fruit are the main negative economic consequences linked to land fragmentation. These driving forces bring only negative effects. Chestnut growers outlined as main driving forces population ageing (score 5/5), land fragmentation (score 5/5), and the economic crisis (score 5/5). They highlighted the negative effects of these driving forces and the consequences of chestnut tree cultivation abandonment. In contrast, local forestry policies, directed towards supporting chestnut growers' income, bring several positive effects for the chestnut landscape: they contribute to increase chestnut cultivation and to preserve traditional cultivation practices and historical chestnut varieties; and, at the same time, they contribute to maintain good quality fruit production. Supporting farm incomes helps strengthen chestnut cultivation and preserve the traditional chestnut growing system. Social and economic needs cause only two positive effects for the chestnut landscape, in terms of chestnut production and cultivation of historical and traditional varieties. The problems with traditional chestnut management encourage the spread of intensive orchards of Euro-Japanese hybrids. Moreover, the relatively high price of chestnut fruits that can be harvested from non-traditional varieties contributes. The traditional product is not adequately valued and therefore the crop is abandoned. Consequently, the mountain landscape and the flat lands where hybrid plants are recently cultivated are changing. The traditional chestnut landscape evolves in the forest and leads to the $C$. sativa cultivar's loss. On the other hand, the presence of new intensive chestnut orchards changes the plain landscape: among cereals or other herbaceous crops and industrial buildings, chestnut-intensive orchards are new elements, recently introduced. Therefore, this land use change can have a positive landscape and environment character for the flat lands, characterized by intensive and monocultural crops.

\subsection{Landscape Scenarios}

Concerning landscape scenarios (Session 2), focus group participants discussed the future of the traditional chestnut landscape. Disappearance/transformation and permanence/maintenance scenarios were built and evaluated. The abandonment of chestnut tree cultivation was the most probable perceived scenario (53\%). Participants hypothesized that after the abandonment, mixed forests would characterize the study area. Of the participants, $41 \%$ supposed that high forest and coppices (biomass production function) would increase. Only $6 \%$ believed that traditional chestnut groves would probably be restored.

The focus group participants were asked to list the main strategies to improve and maintain the traditional chestnut system over the next 20 years. Abandonment and mixed forests not managed, and managed high forest and coppice (biomass function) were considered the main landscape scenarios related to the disappearance and transformation of the traditional chestnut system. Improving chestnut chain systems and increasing the transformation of products were considered the main landscape scenarios related to permanence/maintenance of the traditional chestnut landscape. Figure 4 illustrates the results of permanence/maintenance of traditional chestnut cultivation.

Almost a third (31\%) of focus group participants considered strengthening the chestnut chain system the strategy to conserve the traditional chestnut system, while improved processing of the product, fruit designation of origin, and landscape valorization $(21 \%, 10 \%$, and $10 \%$, respectively) were considered suitable strategies. Quality production valorization (fresh and dried chestnuts), secondary product valorization (honey, mushrooms, wood, and underwood products), touristic activity development, and chestnut cultivation incomes were the other strategies identified by the focus group participants (total equal to $28 \%$ ). For focus group participants, "valorization" meant the strengthening of production values in monetary terms, able to recognize agricultural good practices and landscape conservation trough products selling. 


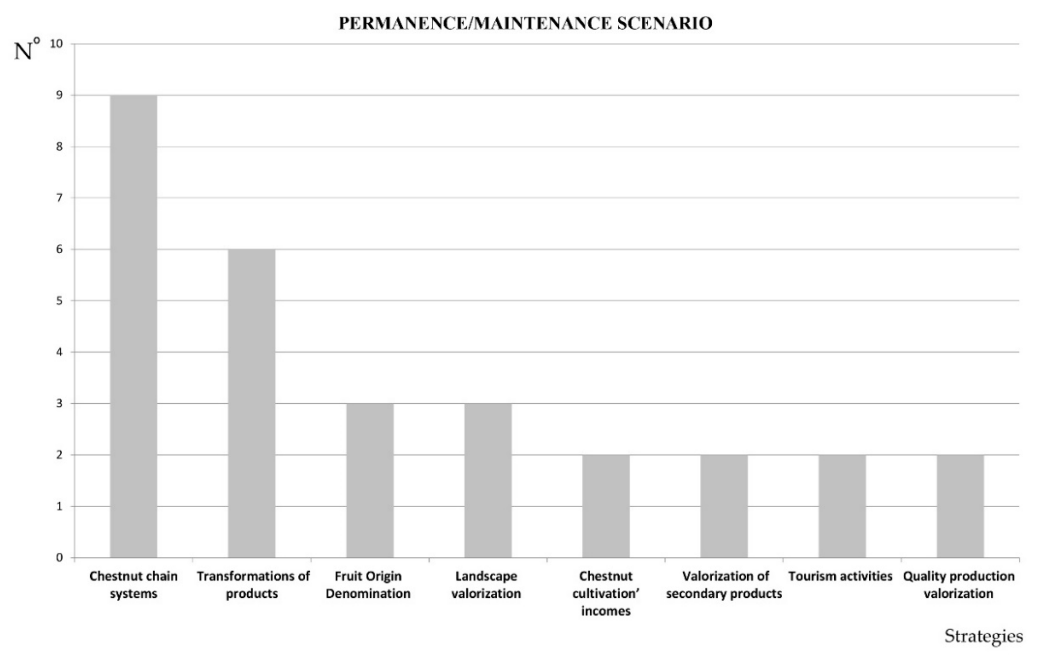

Figure 4. Strategies identified by focus group participants to maintain traditional chestnut cultivation according to the number of preferences received $\left(\mathrm{N}^{\circ}\right)$.

\section{Discussion}

As demonstrated by García de Jalón et al. (2017), a limited number of stakeholders involved in participatory processes generate discussions helping the evaluation of the relative importance of agroforestry system changes [27]. In this context, several authors have explained that scientific research needs to consider the views of local stakeholders, because they are affected by political and administrative decisions $[3,28,36]$. In the present study, analysis of the focus group results allowed the identification of shared driving forces with their direct or indirect landscape effects. All focus group participants expressed the need to protect the traditional chestnut landscape over time. The results of this research highlighted that, to valorize and maintain the traditional chestnut landscape, the most important driving forces are the local forestry policies supporting chestnut growers' income, the demand from young chestnut growers, and the social and economic needs and requirements. In contrast, population ageing and land fragmentation were considered the driving forces that are contributing negatively to change the traditional chestnut landscape. Moreover, these driving forces have caused chestnut cultivation abandonment over time and, nowadays, critical issues related to planning and management occurred.

Using a focus group technique, probable future landscape scenarios were discussed and evaluated. The use of scenarios appeared to foster the visualization of landscape transformations, especially for participants not used to thinking about the landscape. Analyzing the results related to the focus group in Session 1 and Session 2, two interesting aspects emerged. The first aspect is related to the effects of the identified driving forces on the traditional chestnut system; the second is related to landscape scenarios. During Session 2, several strategies were identified, one of which was related to chestnut cultivation income, which was one of the driving forces identified in Session 1. It is interesting that during the scenario evaluation, this strategy was considered secondary. Product processing, fruit designation of origin, and landscape valorization were the most commonly identified strategies. The focus group participants identified driving forces and elements that influence (positively or negatively) the traditional chestnut landscape towards a disappearance/transformation scenario or towards a permanence/maintenance scenario. Figure 5 reports the driving forces and the elements linked to landscape scenarios identified by focus group participants to maintain or transform the traditional chestnut landscape. The traditional chestnut landscape is an unstable forestry system that can change as outlined in the two possible scenarios identified. Related to Session 1, land fragmentation, intensive chestnut growing, the ageing population, and the economic crisis are the main driving forces that will contribute to produce a disappearance/transformation scenario. In contrast, local forestry 
policies directed towards supporting chestnut growers' income, demands from new chestnut growers, and social and economic needs contribute to generate a permanence/maintenance scenario.

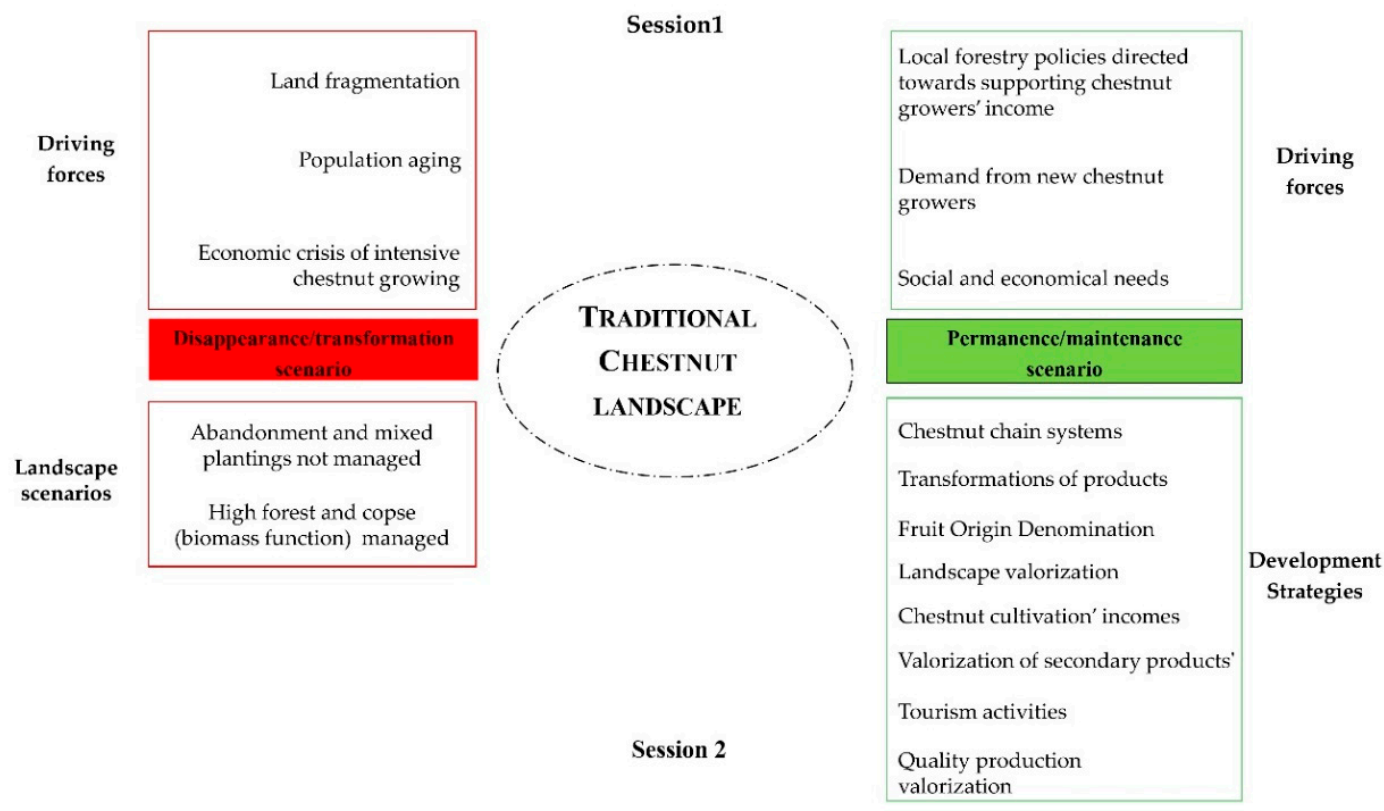

Figure 5. Scheme of the driving forces (Session 1) and the elements linked to landscape scenarios (Session 2) identified by local stakeholders during the focus group discussion that contribute to maintain and transform the traditional chestnut landscape.

Related to Session 2, focus group participants recognized some traditional features as development strategies for maintaining the chestnut landscape. In this challenge, social and economic needs could strengthen and encourage the cultivation of traditional chestnut varieties. By contrast, in relationship to the disappearance/transformation scenario, the focus group participants identified two possible landscape scenarios. In the present study, we have reported in Figure 5 the results acquired in the sessions previously described because we think that these analyses should be integrated with each other. To maintain the traditional chestnut landscape, we can translate the driving forces in specific rural programs and the development strategies in local actions. Therefore, to ensure sustainability of the traditional agricultural landscapes, Gullino et al. (2015) identified strategies and actions reported in the management plan for rural UNESCO sites [37]. With the aim of maintaining the chestnut landscape as a traditional landscape, several strategies identified in this study are the same as for maintaining rural UNESCO sites, including processing, supporting farmers' income, developing tourism activities, and valorizing the landscape.

Gantar and Golobič (2015) and Surova' et al. (2011) affirmed that landscape scenarios could influence attitudes, perspectives, and opinions associated with the traditional landscape [38,39]. The present research has shown that valorization of the landscape and of primary and secondary chestnut products is considered one of the best practices for local stakeholders. In this context, the concept of landscape labeling, as explained by Ghazoul et al. (2009), links specific products with the landscape in which they are produced or obtained [40]. This potential strategy is a tool for a governance approach and holds the promise of rewarding landscape managers and growers for providing products and maintaining goods and services at the landscape level [41]. For chestnut landscape, labeling should be improved, as it highlights its uniqueness and the need for conservation by financing traditional management practices or land uses. During the focus group, the participants recognized landscape labeling as an instrument able to combine traditional elements with product certification on a landscape scale. Labeling in the context of land use commonly implies that special qualities of a landscape justify that the products derived from it are sold at a higher price than those from other areas which do not 
have these qualities. Focus group participants thought that landscape labeling could generate sufficient income for traditional cultural landscapes despite lower productivity than in systems where processes are optimized according to the logic of industrial production. Nowadays this is a tool not used or applied for these traditional sites. According to Roe (2016), labeling plays an important role in map production, attaching specific texts to related geographic, ecological, environmental, and traditional elements to provide clear references [42]. For "map production", Roe recognizes the link between the origin landscape of production and the primary products obtained. As such, people have become more aware of the value of chestnut orchards as multifunctional landscape features. Moreover, the primary and secondary products derived from the traditional chestnut landscape could increase in value in the global market. In this context, the participation of local people is an essential process to identify shared and suitable development strategies [43,44].

The participatory approach contributes to rural landscape planning policy from the local to the regional-national level. Recently, the Piedmont region was identified in the Regional Landscape Plan 76 landscape areas [45]. Thus, the "Pesio Valley" landscape area is included. At regional level, our results were used as tools to identify the "Pesio Valley" area, not only for the geographical definition but for identification of the main dynamics in place and traditional landscape features. Concerning the main dynamics, the driving forces identified by our focus group participants are those highlighted in the Regional Landscape Plan. Moreover, the development strategies are the strategic addresses and guidelines that should be adopted for this landscape area. At national level, the conservation of "traditional rural landscape" is a national priority and some of these cultural sites are nowadays included in the National Register of Historical Rural Landscapes [46]. From this perspective, our study could be considered as a guideline for decision-makers and planners who would characterize the traditional chestnut landscape in the Pesio Valley. For nomination in the National Register of Historical Rural Landscapes, the landscape scenarios identified and the driving forces with their effects are considered preliminary results.

\section{Conclusions}

Through a case study conducted in the Pesio Valley we developed a framework for maintaining traditional chestnut production landscapes and addressing future development policies. The case study described in this paper reveals the main problems that affect this area and offers possible solutions to promote the conservation and development of traditional chestnut landscapes. Despite the small number of focus group participants involved in the research, the focus group could be considered an approach for landscape planning, primarily in threatened traditional agroforestry systems such as the chestnut landscape in Piedmont.

For the traditional chestnut landscape we have identified two possible future scenarios: a disappearance/transformation scenario and a permanence/maintenance scenario. In the present study, focus group participants identified development strategies for maintaining the chestnut landscape. We think that the identification of strategies should be considered a primary step, to be followed by the translation of these strategies into practice. For traditional chestnut landscapes in the Pesio Valley, the concept of traditional landscapes is linked to cultural and historical features and to the maintenance over the centuries of the same land use. In the present studied area, which has rare chestnut varieties and cultivation techniques, the focus group approach is useful to explore the opinions, knowledge, perceptions, and concerns of a small group of individuals. This qualitative research often serves to subsequently produce an extensive and more tailored questionnaire on the object of investigation to a larger number of respondents. In this context, with the aim to manage traditional chestnut landscapes, other stakeholders, for example the residents of the study area, should also be involved. 
Author Contributions: P.G.: conceptualization, formal analysis, methodology, investigation, data collecting, writing original draft, review and editing; M.G.M.: conceptualization, writing original draft, investigation, data collecting, review and editing; G.L.B.: conceptualization, funding acquisition, project administration; M.D.: conceptualization, methodology, data curation, supervision; F.L.: conceptualization, methodology, data curation, supervision review and editing. All authors have read and agreed to the published version of the manuscript.

Funding: This research was supported by PRIN 2010 (University Programs of Scientific Relevance, Italian Ministry of Research and University Education), "Traditional agricultural landscapes in Italy: multi-disciplinary and multi-scale assessment for the development of an integrated model for landscape planning and management".

Acknowledgments: We are grateful to all focus group participants for their essential contribution to the study. The authors declare that the experiment performed was in accordance with current Italian laws. The authors thank the reviewers for their suggestions.

Conflicts of Interest: The authors declare that they have no conflict of interest.

\section{References}

1. Van Berkel, D.B.; Verburg, P.H. Spatial Quantification and Valuation of Cultural Ecosystem Services in an Agricultural Landscape. Ecol. Indic. 2014, 37, 163-174. [CrossRef]

2. Cullotta, S.; Bončina, A.; Carvalho-Ribeiro, S.M.; Chauvin, C.; Farcy, C.; Kurttila, M.; Maetzke, F.G. Forest planning across Europe: The Spatial Scale, Tools, and inter-Sectoral integration in Land-Use Planning. J. Environ. Plann. Manag. 2014, 58, 1384-1411. [CrossRef]

3. Chirwa, P.W.; Mala, W. Trees in the Landscape: Towards The Promotion and Development of Traditional and Farm Forest Management in Tropical and Subtropical Regions. Agrofor. Syst. 2016, 90, 555-561. [CrossRef]

4. Antrop, M. The concept of Traditional Landscapes as a Base for Landscape Evaluation and Planning. The example of Flanders Region. Landsc. Urban. Plan. 1997, 38, 105-117. [CrossRef]

5. Plieninger, T.; Hartel, T.; Martín-López, B.; Beaufoy, G.; Bergmeier, E.; Kirby, K.; Jesús Montero, M.; Moreno, G.; Oteros-Rozas, E.; Van Uytvanck, J. Wood-pastures of Europe: Geographic Coverage, Social-Ecological Values, Conservation Management, and Policy Implications. Biol. Conserv. 2015, 190, 70-79. [CrossRef]

6. Cullotta, S.; Barbera, G. Mapping Traditional Cultural Landscapes in The Mediterranean Area Using A Combined Multidisciplinary Approach: Method and Application to Mount Etna (Sicily; Italy). Landsc. Urban. Plan. 2011, 100, 98-108. [CrossRef]

7. Agnoletti, M. The Degradation of Traditional Landscape in A Mountain Area of Tuscany During the 19th and 20th Centuries: Implications for Biodiversity and Sustainable Management. For. Ecol. Manag. 2007, 249, 5-17. [CrossRef]

8. Conedera, M.; Krebs, P. History, Present Situation and Perspective of Chestnut Cultivation in Europe. Acta Hortic. 2008, 784, 23-28. [CrossRef]

9. Gullino, P.; Larcher, F.; Devecchi, M. The importance of the Chestnut Cultivation and its evolution in the Piedmont Landscape. Acta Hortic. 2010, 866, 37-42. [CrossRef]

10. Hartel, T.; von Wehrden, H. Farmed Areas Predict the Distribution of Amphibian Ponds in a Traditional Rural Landscape. PLoS ONE 2013, 8, e63649. [CrossRef]

11. Plieninger, T.; Höch, F.; Spek, T. Traditional Land-Use and Nature Conservation in European Rural Landscapes. Environ. Sci. Policy 2006, 9, 317-321. [CrossRef]

12. Seijo, F.; Millington, J.D.A.; Gray, R.; Sanz, V.; Lozano, J.; García-Serrano, F.; Sangüesa-Barreda, G.; Camarero, J.J. Forgetting fire: Traditional fire knowledge in two chestnut forest ecosystems of the Iberian Peninsula and its implications for European fire management policy. Land Use Policy 2015, 47, 130-144. [CrossRef]

13. Garbarino, M.; Sibona, E.; Lingua, E.; Motta, R. Decline of Traditional Landscape in a Protected Area of the South western Alps: The Fate of Enclosed Pasture Patches in the Land Mosaic Shift. J. Mt. Sci. 2014, 11, 544-554. [CrossRef]

14. Seijo, F.; Cespedes, B.; Zavala, G. Traditional fire use impact in the aboveground carbon stock of the chestnut forests of Central Spain and its implications for prescribed burning. Sci. Total Environ. 2018, 625, 1405-1414. [CrossRef] [PubMed]

15. Globally-important ingenious Agricultural Heritage Systems GIAHS Project. Report of the Second international Workshop and Steering Committee Meeting. Available online: http://www.fao.org/docrep/015/ ap024e/ap024e.pdf (accessed on 27 October 2019). 
16. Gullino, P.; Larcher, F. Integrity in UNESCO World Heritage Sites. A comparative study for rural landscapes. J. Cult. Herit. 2013, 14, 389-395. [CrossRef]

17. Agnoletti, M.; Cargnello, G.; Gardin, L.; Santoro, A.; Bazzoffi, P.; Sansone, L.; Pezza, L.; Belfiore, N. Traditional Landscape and Rural Development: Comparative Study in Three Terraced Areas in Northern, Central and Southern Italy to Evaluate the Efficacy of GAEC Standard 4.4 of Cross Compliance. Ital. J. Agron. 2011, 6, 121-139. [CrossRef]

18. Biasi, R.; Botti, F.; Barbera, G.; Cullotta, S. The Role of Mediterranean Fruit Tree Orchards and Vineyards in Maintaining the Traditional Agricultural Landscape. Acta Hortic. 2012, 940, 79-88. [CrossRef]

19. Mattioli, W.; Mancini, L.D.; Portoghesi, L.; Corona, P. Biodiversity conservation and forest management: The case of the sweet chestnut coppice stands in Central Italy. Plant Biosyst. 2016, 15, 592-600. [CrossRef]

20. Beccaro, G.; Alma, A.; Bounous, G.; Gomes-Laranjo, J. The Chestnut Handbook: Crop E Forest Management; CRC Press: Boca Raton, FL, USA, 2019; p. 378. ISBN 9780429445606.

21. Torello Marinoni, D.; Akkak, A.; Beltramo, C.; Guaraldo, P.; Boccacci, P.; Bounous, G.; Ferrara, A.M.; Ebone, A.; Viotto, E.; Botta, R. Genetic and morphological characterization of chestnut (Castanea sativa Mill.) germplasm in Piedmont (north-western Italy). Tree Genet. Genom. 2013, 9, 1017-1030. [CrossRef]

22. Pezzi, G.; Maresi, G.; Conedera, M.; Ferrari, M. Woody Species Composition of Chestnut Stands in The Northern Apennines: The Result of 200 Years of Changes in Land Use. Landsc. Ecol. 2011, 26, 1463-1476. [CrossRef]

23. Mellano, M.G.; Gullino, P.; Larcher, F.; Beccaro, L.G. A Multidisciplinary and Multiscale interpretative Model To Plan and Manage Traditional Chestnut Landscape in Italy. Act. Hortic. 2018, 1220, 121-124. [CrossRef]

24. Conedera, M.; Tinner, W.; Krebs, P.; de Rigo, D.; Caudullo, G. Castanea sativa in Europe: Distribution, Habitat, Usage and Threats; European Atlas of Forest Tree Species; San-Miguel-Ayanz, J., de Rigo, D., Caudullo, G., Houston Durrant, T., Mauri, A., Eds.; Publication Office of EU: Luxembourg, 2016.

25. Larcher, F.; Gullino, P.; Mellano, M.G.; Beccaro, G.L.; Devecchi, M. Integrating historical and Social Knowledge For Restoring and Planning Traditional Fruit Landscape in Piedmont (Italy). Acta Hortic. 2017, 1189, 339-342. [CrossRef]

26. Pástor, M.; Slámová, M.; Benčat', T. The Distribution and Biocultural Value Assessment of Sweet Chestnut (Castanea Sativa Mill.) in The Cadastral Districts of Stredné Plachtince and Horné Plachtince (Slovakia). Ekologia Bratislava 2017, 36, 130-145. [CrossRef]

27. García de Jalón, S.; Burgess, P.J.; Graves, A.; Moreno, G.; McAdam, J.; Pottier, E.; Novak, S.; Bondesan, V.; Mosquera-Losada, R.; Crous-Durán, J.; et al. How is agroforestry perceived in Europe? An assessment of positive and negative aspects by stakeholders. Agrofor. Syst. 2018, 92, 829-848. [CrossRef]

28. Lourenço-Gomes. L.; Costa Pinto, L.M.; Rebelo, J.F. Visitors' preferences for preserving the attributes of a world heritage site. J. Cult. Herit. 2014, 15, 64-67. [CrossRef]

29. Italian Statistical National Institute, Census of Agriculture. Caratteristiche strutturali delle aziende agricole. Fascicolo Provinciale Cuneo. Istituto Nazionale di Statistica [Structural characteristics of farms. Agricultural census Cuneo Province. National Institute of Statistics], 1st ed.; Italian Statistical National Institute: Rome, Italy, 2014.

30. Torello Marinoni, D.; Sartor, C.; Ruffa, P.; Akkak, A.; Mellano, M.G.; Beccaro, G.L.; Bounous, G.; Botta, R. A multidisciplinary approach to preserve and value the chestnut heritage. Acta Hortic. 2014, 1043, 135-138. [CrossRef]

31. Istituto per le Piante da Legno e l'Ambiente. Indirizzi per la Gestione e Valorizzazione Boschi Collinari; Regione Piemonte, Blu Edizioni: Torino, Italy, 2001.

32. Atwell, R.C.; Schulte, L.A.; Westphal, L.M. Tweak, Adapt, or Transform: Policy Scenarios in Response to Emerging Bioenergy Markets in the U.S. Corn Belt. Ecol. Soc. 2011, 16, 1-10. Available online: http://www.ecologyandsociety.org/vol16/iss1/art10/ (accessed on 21 December 2020). [CrossRef]

33. Gullino, P.; Devecchi, M.; Larcher, F. How Can Different Stakeholders Contribute To Rural Landscape Planning Policy? The Case Study of Pralormo Municipality (Italy). J. Rural Stud. 2018, 57, 99-109. [CrossRef]

34. Loupa Ramos, I. 'Exploratory landscape scenarios' in the formulation of 'landscape quality objectives'. Futures 2010, 42, 682-692. [CrossRef]

35. Ramirez, R.; Mukherjee, M.; Vezzoli, S.; Kramer, A.M. Scenarios as a scholarly methodology to produce “interesting research". Futures 2015, 71, 70-87. [CrossRef]

36. Opdam, P.; Coninx, I.; Dewulf, A.; Steingröver, E.; Vos, C.; van der Wal, M. Framing ecosystem services: Affecting behaviour of actors in collaborative landscape planning? Land Use Policy 2015, 46, 223-231. [CrossRef] 
37. Gullino, P.; Beccaro, G.L.; Larcher, F. Assessing and Monitoring the Sustainability in Rural World Heritage Sites. Sustainability 2015, 7, 14186-14210. [CrossRef]

38. Gantar, D.; Golobič, M. Landscape scenarios: A study of influences on attitudes and actions in a rural landscape. Futures 2015, 69, 1-13. [CrossRef]

39. Surová, D.; Surový, P.; de Almeida Ribeiro, N.; Pinto-Correia, T. Integrating Differentiated Landscape Preferences in A Decision Support Model for the Multifunctional Management of the Montado. Agrofor. Syst. 2011, 82, 225-237. [CrossRef]

40. Ghazoul, J.; Garcia, C.; Kushalappa, C.G. Landscape labelling: A Concept For Next-Generation Payment For Ecosystem Service Schemes. For. Ecol. Manag. 2009, 258, 1889-1895. [CrossRef]

41. Mann, C.; Plieninger, P. The Potential of Landscape Labelling Approaches For integrated Landscape Management in Europe. Landsc. Res. 2017, 42, 904-920. [CrossRef]

42. Roe, M. Editorial: Food and landscape. Landsc. Res. 2016, 41, 709-713. [CrossRef]

43. Primdahl, J.; Kristensen, L. Landscape Strategy Making and Landscape Characterisation-Experiences From Danish Experimental Planning Processes. Landsc. Res. 2016, 41, 227-238. [CrossRef]

44. Mauchline, A.L.; Mortimer, S.R.; Park, J.A.; Finn, J.A.; Haysom, K.; Westburya, D.B.; Purvis, G.; Louwagie, G.; Northey, G.; Primdahl, J.; et al. Environmental Evaluation of Agri-Environment Schemes Using Participatory Approaches: Experiences of testing the Agri-Environmental Footprint index. Land Use Policy 2012, 29, 317-328. [CrossRef]

45. Piedmont Region. Regional Landscape Plan. Schede ambiti di paesaggio. Pesio Valley. 2017. Available online: www.regione.piemonte.it/web/sites/default/files/media/documenti/2019-03/d_Schede_degli_ambiti_ di_paesaggio.pdf (accessed on 26 November 2020).

46. Ministry of Agricultural, Food and Forestry Policies. Registro Nazionale dei Paesaggi Rurali Storici. Available online: www.reterurale.it/registropaesaggi (accessed on 26 November 2020).

Publisher's Note: MDPI stays neutral with regard to jurisdictional claims in published maps and institutional affiliations.

(C) 2020 by the authors. Licensee MDPI, Basel, Switzerland. This article is an open access article distributed under the terms and conditions of the Creative Commons Attribution (CC BY) license (http://creativecommons.org/licenses/by/4.0/). 